\title{
MANAJEMEN PERPUSTAKAAN SEKOLAH MENENGAH ATAS (STUDI KASUS SMA NEGERI TERAKREDITASI A KOTA PONTIANAK)
}

\author{
Eka Jaya PU, Pujo Sukino, dan Hana Mauludea \\ Prodi Pendidikan Sejarah, Fakultas Ilmu Pendidikan dan Pengetahuan Sosial \\ IKIP PGRI Pontianak \\ ekajpu.ikipptk@gmail.com
}

\begin{abstract}
Abstrak
Penelitian ini bertujuan untuk mengetahui manajemen perpustakaan SMA Negeri di Kota Pontianak yang terakreditasi A. Metode penelitian yang digunakan yakni kualitatif deskriptif analitik dan studi kasus tunggal. Pengumpulan data dengan wawancara, observasi dan mengkaji dokumen. Analisis data dengan model interaktif. Hasil penelitian menunjukkan bahwa pengelolaan perpustakaan berjalan sesuai kebutuhan dan kemampuan sekolah dalam memberikan pelayanan kepada siswa namun secara praktik bahwa prosedur pelaksanaan pelayanan dari beberapa sekolah belum sesuai dengan pokok-pokok fungsi manajemen perpustakaan sekolah. Seperti fasilitas ruangan, buku, tenaga perpustakaan yang diantaranya belum memiliki sertifikat pelatihan dan pendidikan perpustakaan. Kendala yang dihadapi menjadi kritik yang memberikan perbaikan dikemudian hari dan masalah ini dapat diatasi dengan strategi masing-masing sekolah serta bantuan pihak pemerintah Kota Pontianak.
\end{abstract}

Kata kunci: Manajemen, Perpustakaan, SMA di Pontianak.

\section{Abstrak}

This study aims to determine the management of the State Senior School libraries in Pontianak Accredited $A$. The research method used is qualitative descriptive analytics and single case study. Data collection by interviewing, observing and reviewing documents. Data analysis with interractive model. The result of the research shows that library management runs according to the need and ability of school in giving service to students but in practice that procedure of service execution from some school not yet in accordance with principal of school library management function. Such as room facilities, books, libraries that do not have the certificate of training and education of the library. Constraints faced to criticism that provide improvements in the future and this problem can be overcome with the strategy of each school and the help of the government of Pontianak City.

Key words : Management, Library, SMA in Pontianak. 


\section{PENDAHULUAN}

Indonesia adalah negara kepulauan yang Perpustakaan sekolah merupakan salah satu sarana pendidikan penunjang kegiatan belajar siswa dalam mencapai tujuan pendidikan. Salah satu masalah yang dihadapi dalam dunia pendidikan adalah masalah lemahnya proses pembelajaran (ejournal.unesa.ac.id/artide). Proses pembelajaran hanya terpusat di dalam kelas, yakni kemampuan yang diarahkan untuk menghafal informasi. Otak siswa dipaksa untuk mengingat dan menimbun berbagai informasi tanpa dituntut untuk memahami informasi yang diingatnya.

Berdasarkan Undang-Undang RI No. 20 Tahun 2003 tentang Sistem Pendidikan Nasional pasal 3, dijelaskan bahwa pendidikan nasional berfungsi untuk mengembangkan kemampuan dan membentuk watak serta peradaban bangsa yang bermartabat dalam rangka mencerdaskan kehidupan bangsa, bertujuan untuk berkembangnya potensi peserta didik agar menjadi manusa yang beriman dan bertakwa kepada Tuhan Yang Maha Esa, berakhlak mulia, sehat, berilmu, cakap, kreatif, mandiri, dan menjadi warga negara yang demokratis serta bertanggung jawab. Dengan demikian, pendidikan nasional memiliki tujuan yang sangat luas tidak saja terkait dengan kecakapan akademik, melainkan pula kecakapankecakapan lain seperti religius, kepribadian dan sosial.

Dalam rangka mengembangkan pendidikan dan pembelajaran bagi siswa, perpustakaan adalah satu sarana pembelajaran dapat menjadi sebuah kekuatan untuk mencerdaskan bangsa. Tidak hanya itu, perpustakaan sekaligus menjadi tempat yang menyenangkan bagi berbagai kalangan yang menggunakannya sebagai upaya mencari informasi sebanyakbanyaknya. Perpustakaan sudah banyak berdiri dimana-mana, namun persoalannya adalah bagaimana pengelolaanya atau manajemennya sehingga perpustakaan dapat memberikan pelayanan dan saranan pembelajaran baik bagi masyarakat umum maupun siswa di sekolah.

Usaha peningkatan kualitas pendidikan akan berlangsung baik jika didukung oleh kompetensi dan kemauan para pengelola pendidikan untuk melakukan perbaikan secara terus-menerus kearah yang lebih baik. Dengan demikian, inovasi pendidikan secara berkesinambungan dalam program pendidikan termasuk program pemanfaatan perpustakaan sekolah sebagai sarana penunjang dalam memberikan pelayanan kepada siswa.

Dari diuraikan di atas, bahwa perpustakaan adalah suatu unit kerja yang mengelola bahan-bahan pustaka dan harus dikelola dengan sebuah manajemen yang sudah ditetapkan pemerintah melalui Peraturan Pemerintah No.24 Tahun 2014 tentang Perpustakaan dan Peraturan Pemerintah No.25 tahun 2008 tentang Tenaga Perpustakaan. Fokus masalah yang diangkat dalam penelitian ini "Bagaimanakah Manajemen Perpustakaan Sekolah Menengah Atas (Studi Kasus SMA Negeri terakreditasi A di Kota Pontianak)".

\section{METODE}

Bentuk penelitian ini adalah kualitatif deskriptif yaitu penelitian yang menyajikan temuan dalam bentuk deskriptif kalimat yang rinci, lengkap, dan mendalam yang menggambarkan situasi sebenarnya guna mendukung penyajian data. Data yang dikumpulkan berupa kata-kata, kalimat atau gambar yang memiliki arti lebih bermakna dari pada sekedar penyajian angka atau frekuensi (Sutopo, 2006 :40) selain itu, semua yang dikumpulkan berkemungkinan menjadi kunci terhadap apa yang sudah diteliti (J. Moloeng Lexy, 2012:12)

Penelitian ini termasuk penelitian dasar yang menekan pada objek dan fakta-fakta yang tampak yaitu manajemen perpustakaan sekolah menengah atas di Kota Pontianak yang mendapatkan nilai akreditasi A oleh Badan Akreditasi Sekolah. Strategi yang digunakan adalah studi kasus tunggal, karena penelitan ini dilaksanakan pada tempat yang satu level. Jenis penelitan ini lebih khusus disebut studi kasus tunggal terpancang atau embedded case study (Sutopo, 2006: 180), karena fokus penelitian telah di tentukan sebelum penelitan terjun menggali informasi data di lapangan. Subjek penelitian ini yaitu kepala perpustakaan 
sekolah, kepala sekolah, tenaga administrasi perpustakaan, guru dan siswa.

Teknik pengumpulan data dalam penelitian berupa wawancara, observasi, dan dokumen. Untuk menjamin kredibilitas, kemantapan dan atau kebenaran data yang diperoleh maka data harus diuji validitasnya melalui triangulasi sumber, metode dan teori. Teknik analisis data dilakukan dalam bentuk interaktif. Proses interaktif ini juga dilakukan dengan membandingkan data yang diperoleh melalui wawancara dengan data hasil observasi, arsip dan sebagainya sebagai usaha pemantapan simpulan yang dicoba untuk dikembangkan dan validitas datanya dengan melihat tingkat kesamaannya, perbedaanya, atau kemungkinan lainnya (Sutopo, 2006:107). Menurut pendapat Miles M.B \& Huberman A.M (1992:16) "Dalam model analisis ini terdapat tiga komponen yang harus dipahami oleh para peneliti yaitu reduksi data, sajian data dan penarikan simpulan/ verifikasi".

\section{HASIL DAN PEMBAHASAN}

Pengelolaan inventaris dari sekolahsekolah yang terakreditasi A pada umumnya hampir sama, yaitu pengadaan bukunya berasal dari dinas dan bersumber dari buku sumbangan siswa yang akan lulus sekolah. Dalam pengadaan buku, pihak pengelola terlebih dahulu membuat daftar buku ajuan yang dibutuhkan untuk koleksi perpustakaan. Seperti yang diungkapkan oleh pengelola perpustakaan SMA Negeri 5 Pontianak, bahwa pengajuan buku berdasarkan kebutuhan siswa dan buku pengganti yang sudah rusak. Kemudian diserahkan kepada kepala sekolah, yang diteruskan pengajuannya kepada Dinas Pendidikan Kota Pontianak. Hal ini sudah menjadi agenda tahunan. Buku-buku yang telah diajukan hanya sekitar $77 \%$ buku saja yang direalisasikan. Buku yang diajukan banyak diantaranya adalah buku pelajaran. Sedangkan buku referensi jarang sekali disetujui.

Ada pula permintaan lain dari siswa adalah buku novel. Seperti yang disampaikan pengelola perpustakaan di SMA Negeri 2 Pontianak, dikatakan bahwa buku yang ada diper- pustakaan sebagian besar buku pelajaran. Buku yang sifatnya penunjang setiap mata pelajaran juga ada namun merupakan koleksi lama. Ada beberapa koleksi buku ensiklopedia dan referensi hanya saja jumlahnya terbatas karena harganya mahal dan dibeli menggunakan dana Bantuan Oprasional Sekolah (BOS). Hal senada terjadi di SMA Negeri 10 Pontianak mengaku sumber utama sumbangan buku di perpustakaan adalah Dinas Pendidikan Kota Pontianak dan dari sumbangan siswa. Ada juga buku yang dibeli dari dana sekolah namun terbatas sehingga tidak bisa dipinjamkan untuk di bawa pulang, hanya khusus dibaca di ruang perpustakaan.

Secara fisik, jenis koleksi yang diperlukan untuk suatu perpustakaan sekolah bisa dikelompokkan ke dalam kategori buku dan bahan bukan buku. Pertama meliputi segala jenis buku dan yang terakhir meliputi segala jenis bahan yang tidak termasuk ke dalam kategori. Buku bisa bermacam-macam jenisnya, yakni buku yang bermateri fiksi maupun buku yang bersifat non fiksi. Baik yang pertama maupun yang kedua masing-masing masih banyak variasi dan jenis dilihat dari segi isi maupun bentuk penyajiannya. Misalnya yang termasuk buku-buku fiksi antar lain ada fiksi umum, fiksi ilmiah, dan fiksi sastra. Sedangkan yang termasuk dalam buku-buku non fiksi antara lain meliputi buku-buku ilmiah, ilmiah popular, informasi umum, dan informasi khusus, termasuk di dalamnnya buku teks.

Pengelompokan yang sistematis dari pada sejumlah obyek, gagasan, buku atau benda-benda lain ke dalam kelas atau golongan tertentu berdasarkan ciri-ciri yang sama. Dalam proses klasifikasi bahan pustaka dipergunakan penggolongan berdasarkan ciri tertentu. Misalnya oleh karena bentuk fisik yang berbeda, maka penempatan buku perpustakaan dipisahkankan dari surat kabar, majalah, piringan hitam, microfilm dan slides. Secara keseluruhan koleksi perpustakaan sekolah isinya mengandung bahan bahan yang menunjang program sekolah, baik program kulikuler maupun ekstra kulikuler (Oktaviana dan Irhandayaningsih, 2014: 4). 
Sistem penyusunan koleksi buku-buku perpustakaan dibagi dalam beberapa bagian yaitu buku paket yang terdiri dari beberapa mata pelajaran; buku-buku penunjang sesuai bidang seperti buku keagamaan, buku sejarah dan kewarganegaraan, buku sosiologi, buku ekonomi, buku orahraga, buku geografi, buku TIK, buku sastra, buku fisika, buku biologi, buku ensiklopedia, buku referensi berbagai bidang ilmu, buku muatan lokal. Setiap bidang buku tersebut dikelompokkan ke dalam sebuah rak yang di lengkapi dengan kode. Selayaknya inventarisasi buku dalam perpustakaan sudah efektif, kenyataannya di sekolah masih belum melakukan hal tersebut.

Semua sekolah-sekolah sudah melakukannya dengan baik dan bekerja sesuai tugas dan fungsi pengelolanya. Sekolah Menengah Atas negeri yang mendapatkan nilai akreditasi A, dirasa sangat wajar ketika sistem inventarisasinya dilakukan dengan baik. Hal serupa tentunya menjadi harapan semua stakeholder pendidikan, agar tujuan pendidikan dapat berjalan dan tercapai sesuai target.

Namun tidak jarang buku yang sudah dibaca oleh siswa tidak diletakkan pada tempat asal buku tersebut diambil. Akhirnya buku tidak tertata rapi seperti semula, dan ini mengharapkan kerja keras dari pengelola perpustakaan untuk merapikan buku yang bertaburan di rak-raknya. Dalam perpustakaan yang tersedia hanyalah bahan pustaka dan didominasi oleh buku teks mata pelajaran sesuai rombongan belajaranya. jarang ditemui sumber bacaan lain seperti Koran, majalah, bulletin, jurnal dan bahkan hasil karya ilmiah baik dari guru maupun hasil penelitian lainnya. Kemudian proses inventarisasi perpustakaan sekolah dalam mendata jumlah buku baik judul maupun banyaknya setiap eksemplar buku dilakukan secara manual. Artinya proses pembuatan catalog masih dengan dicatat pada sebuah buku agenda. Tetapi sebagian sekolah-sekolah proses inventarisasi ada yang memanfaatkan sistem komputerisasi.

Pendanaan adalah sesuatu yang sering menjadi kendala bagi pengelola perpustakaan dalam mengembangkan perpustakaannya. Se- perti yang sudah di sampaikan sebelumnya bahwa untuk pengadaan buku. Pengelola perpustakaan dalam hal ini kepala sekolah mengalami kesulitan dalam membagi dana yang dikelola sebagian dari dana BOS. Pengadaan buku masih terpusat pada sumbangan dari pemerintah dan sumbangan siswa. Disamping itu kendala yang dihadapai oleh sekolah dalam pengelolaan perpustakaannya yakni karena kurangnya tenaga ahli yang berkompeten dalam bidang perpustakaan. Hal serupa ditambah dengan koleksi buku yang masih lama sehingga informasi yang di baca oleh siswa terbatas pada sumber lama. Lain pihak bahwa pemerintah dalam hal ini Dinas Pendidikan belum secara optimal memberikan pelayanan dan dukungan baik berupa dana maupun tenaga. Kemudian waktu yang digunakan oleh siswa dalam memanfaatkan perpustakaan sebagai sumber mendapatkan informasi hanya pada jam-jam istirahat. Sehingga keterbatasan waktu juga menjadi masalah yang agak sulit dipecahkan oleh guru.

Kepala sekolah adalah penanggungjawab seluruh kegiatan di perpustakaan sekolah. Bertugas memberikan arahan, bimbingan dan pengawasan kepada kepala perpustakaan. Peran guru dalam memanfaatkan perpustakan bisa dikatakan cukup membangun minat baca siswa dan membuat siswa sering mengunjungi perpustakaan. Berdasarkan hasil observasi, wawancara dengan guru dan pengelola perpustakaan sekolah bahwa perpustakaan sebagai tempat aktivitas belajar atau yang biasanya siswa belajar di dalam kelas sesekali guru membawa siswa belajar di perpustakaan.

Menurut guru "setidaknya siswa menjadi tidak bosan ketika belajar kita bisa berganti suasana. Ketika kita membutuhkan contoh atau sumber lain tinggal ambil saja di rak buku dan pembahasan semakin luas". Pada saat tertentu siswa berkunjung di perpustakaan sekolah dengan maksud meminjam buku dalam rangka menghadapi ujian. Artinya guru dan kepala sekolah dalam pemanfaatan perpustakaan belum maksimal karena siswa beranggapan bahwa perpustakaan adalah bagian kecil yang dapat membantu siswa untuk memecahkan masalah. 
Sehingga perpustakaan sering ditemui masih sepi pengunjung.

Standar kualifikasi pada umumnya sekolah-sekolah penyelenggara pendidikan dan memiliki perpustakaan dengan membentuk struktur organisasi perpustakaan. Peran kepala sekolah sangat penting untuk memutuskan seorang pengelola perpustakaan, baik sebagai kepala maupun tenaga perputakaan. Keputusan kepala sekolah dalam memberikan kepercayaan kepada guru ataupun tenaga kependidikan untuk mengelola perpustakaan melalui proses musyawarah dan kajian tertentu.

Dengan demikian kepala dan pengelola perpustakaan diharapkan memahami dan dapat menjalankan fungsi dan tugasnya sebagaimana yang telah diatur dalam peraturan tentang pengelolaan perpustakaan sekolah. Fakta di lapagan dari hasil wawancara dan pengamatan lapangan menunjukkan bahwa hampir semua pengelola perpustakaan sudah mendapatkan pelatihan dari Dinas Pendidikan Kota Pontianak dan Perpustakaan Provinsi Kalimantan Barat. Hanya belum mendapatkan sertifikat pendidikan perpustakaan yang diselenggarakan oleh asosiasi maupun perguruan tinggi yang ditunjuk Pemerintah.

Pada dasarnya penyelenggara perpustakaan tidak hanya peran dari sekolah dan pengelolanya. Masyarakat juga harus dilibatkan, sesuai dengan Undang-Undang Nomor 43 Tahun 2007 tentang perpustakaan, bahwa yang berkewajiban untuk membangun dan menjaga eksistensi perpustakaan adalah seluruh warga negara. Perpustakaan sekolah merupakan salah satu bentuk dari beberapa jenis perpustakaan yang ada di Indonesia. Sehingga yang menjadi penyelenggara utamanya adalah sekolah dan di bawah pimpinan kepala sekolah. Peran kepala sekolah adalah memberikan arahan, bimbingan dan pengawasan kepada kepala perpustakaan. Peran guru dalam memanfaatkan perpustakan adalah unsure terpenting agar menjadi ujung tombak bagi siswanya.

Aktivitas siswa di perpustakaan sekolah masih dirasa kurang. Penyebab utamanya adalah rendahnya kesadaran siswa dan menganggap perpustakaan belum memberikan kontribusi apapun. Membangun minat baca siswa bagian tugas guru. Tidak jarang didapatkan kondisi perpustakaan dalam keadaan sepi. Tugas mata pelajaran dari guru dapat dijadikan langkah awal agar siswa mau berkunjung dan belajar di perpustakaan. Pelajaran Bahasa Indonesia yang sering dijadikan para siswa menyelesaikan tugasnya. Tetapi tidak menutup kemungkinan mata pelajaran lain pun sering gurunya memberikan tugas untuk dikerjakan di perpustakaan.

Sumber dari semua ilmu pengetahuan adalah perpustakaan. Minat baca dan kesadaran akan pentingnya sumber belajar masih rendah. Oleh karena itulah guru dalam hal ini sebagai motor untuk mengerakkan siswa dalam membaca dan memanfaatkan perpustakaan menjadi kendala besar. Himbauan dan sosialisasi sering dilakukan baik melalui seminar, maupun sekarang ada perpustakaan keliling disetiap kecamatan. Pada akhirnya tidak berguna untuk menumbuhkan minat dan kesadaran pentingnya membaca.

Kepala sekolah dan dewan guru hingga saat ini masih tidak bosan-bosannya untuk memotivasi siswanya. Baik disampaikan dalam situasi formal maupun non formal. Padahal kepentingan tersebut bukan semata untuk guru, melainkan berpihak untuk siswa. Pola pikir dan kebutuhan siswa di era globalisasi ini menuntut dan memberikan ruang kepada mereka untuk mendapatkan informasi jauh lebih cepat. Bisa jadi inilah alasan sulitnya siswa kembali dan memanfaatkan perpustakaan sekolah sebagai sumber belajar.

Pada umumnya perpustakaan sekolah hanya dikelola sedikit orang, bahkan hanya satu orang. Kondisi ini memang memprihatinkan, sebab semestinya tidak boleh demikian, kecuali kalau muridnya memang sedikit. Perpustakaan sekolah haruslah dikelola oleh beberapa orang, karena di dalam perpustakaan terdapat beberapa bagian pekerjaan (Kementerian Pendidikan Nasional, 2010: 21).

Dalam Undang-Undang Nomor 43 tahun 2007 tentang Perpustakaan dijelaskan bahwa standar kualifikasi organisasi perpustakaan dipandang dari beberapa unsur. Tenaga per- 
pustakaan terdiri dari pustakawan dan tenaga teknis perputakaan. Tenaga perpustakaan berhak mendapatkan tunjangan atau gaji sesuai tugasnya dalam organisasi perpustakaan. Sepanjang pendidikan dari seorang tenaga teknis maupun pustakawan sesuai maka seharusnya tunjangannya dapat diperoleh. Disamping itu juga bahwa pustakawan harus masuk dalam sebuah organisasi perpustakaan, sebagai bentuk perlindungannya.

Dengan demikian kepala dan pengelola perpustakaan diharapkan memahami dan dapat menjalankan fungsi dan tugasnya sebagaimana yang telah diatur dalam peraturan tentang pengelolaan perpustakaan sekolah. Hampir semua pengelola perpustakaan sudah mendapatkan pelatihan dari dinas pendidikan Kota Pontianak dan Perpustakaan provinsi Kalimantan Barat. Maksudnya adalah profesionalitas tenaga perpustakaan sudah harus seimbang dengan kebutuhan dan keberadaan perpustakaan di sekolahnya masing-masing.

Pemerintah dalam hal ini perpustakaan wilayah Provinsi Kalimantan Barat selalu ikut serta mensosialisasikan perpustakaan sebagai sumber informasi dan pengetahuan. Bahkan pelatihan pengelolaan perpustakaan sekolah menjadi agenda rutin tahunan. Selama ini sekolah sudah menjalankan misi dan program pemerintah. Persoalan keberhasilan setiap sekolah dalam mengelola dan mengembangkan perpustakaan, masing-masing memilki penilaian sendiri. Namun yang jelas keberhasilan tidak dilihat secara macro, seiring kebutuhan dan sumber daya manusia dalam mengelolanya juga bagian terpenting untuk mencapai tujuan.

Peraturan yang tertuang dalam tata tertib perpustakaan tidak berjalan secara maksimal. Misalnya terdapat buku yang rusak, dan mengembalikan tidak sesuai waktu yang ditentukan. Tidak diberikan sanksi sesuai aturan yang dibuat. Berarti pengelola perpustakaan tidak konsisten dalam menerapkan kedisiplinan terhadap siswa.

\section{SIMPULAN}

Proses pengelolaan inventarisasi per- pustakaan Sekolah Menengah Atas Negeri yang terakreditasi A di Kota Pontianak, mengalami beberapa kendala yang diantaranya saat pengadaan buku kepada pemerintah. Kemudian penataan ruangan belum standar disebabkan oleh gedung yang pembangunannya dengan dana yang terbatas. Koleksi bahan pustaka di perpustakaan sekolah sudah mengakomodir semua rombongan belajar. Karena bahan pustaka berupa non fiksi merupakan sumber bacaan utama bagi siswa. Terutama untuk membantu siswa dalam menyelesaikan tugas-tugas dari gurunya.

Hal-hal yang menjadi faktor penghambat dalam rangka pelaksanaan manajemen perpustakaan sekolah yaitu minimnya dana operasional yang dimiliki perpustakaan. Sehingga untuk membangun dan mengembangkan fasilitas perpustakaan sekolah menjadi terhambat. Peran kepala sekolah dan guru turut serta menjadi bagian terpenting dalam pengembangan dan pemanfaatan perpustakaan sekolah. Hal yang paling penting adalah guru selalu memberikan materi yang berorientasi pada kebutuhan akan buku. Petugas yang sudah ditetapkan oleh kepala sekolah untuk mengelola perpustakaan dirasa cukup ideal.

\section{UCAPAN TERIMA KASIH}

Terima kasih penulis ucapkan kepada para informan yang terlibat dalam penelitian ini, terutama perpustakaan SMA Negeri di Kota Pontianak yang terakreditasi A, sehingga penelitian ini dapat berjalan dengan baik. Selain itu kami ucapkan terima kasih kepada pihak-pihak yang turut membantu support dana sehingga penelitian inidapat berjalan dengan lancar. Terima kasih kepada redaksi yang telah mempublikasikan artikel hasil penelitian ini.

\section{DAFTAR PUSTAKA}

Kementerian Pendidikan Nasional. 2010. Manajemen Perpustakaan Sekolah. Direktorat Jenderal Peningkatan Mutu Pendidik dan Tenaga Kependidikan, Direktorat Tenaga Pendidikan.

Lexy, J Moloeng. 2012. Metodologi Penelitian Kualitatif. Bandung: Remaja Rosdakarya. 
Miles M.B. dan Huberman A.M. 1992.

Oktaviana, Devi dan Irhandayaningsih, Ana. 2014. Peranan Perpustakaan Raditya Dalam Pengembangan Pendidikan Karakter Siswa di SMA Negeri 1 Lasem. Jurnal Ilmu Perpustakaan, 3 (1): 11-21

Peraturan Pemerintah Republik Indonesia Nomor 25 Tahun 2008

Peraturan Pemerintah Republik Indonesia No- mor 24 Tahun 2014 Tentang Perpustakaan Sutopo, H B 2006. Metodologi Penelitian Kualitatif. Surakarta: Universitas Sebelas Maret Press.

Undang-Undang Republik Indonesia Nomor 20 Tahun 2003 Tentang Sistem Pendidikan Nasional

Undang-Undang Republik Indonesia Nomor 43 Tahun 2007 Tentang Perpustakaan 